Terri Kim (2014) The intellect, mobility and epistemic positioning in doing comparisons and

comparative education, Comparative Education, 50:1, 58-72, DOI: 10.1080/03050068.2013.874237

\title{
The Intellect, Mobility and Epistemic Positioning in doing Comparisons and Comparative Education
}

\author{
Terri Kim \\ University of East London
}

\begin{abstract}
This article offers a reflexive analysis and discussion on the relationship between academic mobility and comparative knowledge creation. It argues that what constitutes 'comparative knowledge' is not solely Wissenschaften but more often entwined with Weltanschauungen, derived from lived experiences - as exemplified in the biographic narratives of some of the major intellects. It reviews the notions of the 'gaze' and the concepts of the Other and Homeworld/Alienworld as epistemic positioning in doing comparative education. In the framework of phenomenological thinking, the paper discusses the intimate relationship between comparative knowledge and positional knowledge.
\end{abstract}

\section{Bio note}

Terri Kim is Reader (designate) in the Cass School of Education and Communities, University of East London (effective $8^{\text {th }}$ April 2013) and Associate in the Centre for Higher Education Studies (CHES), Institute of Education, University of London. As a specialist in Comparative Higher Education, she has been a full-time Lecturer at Brunel University. She gained her PhD at the University of London, Institute of Education in 1998, and previously worked as a research consultant for OECD/CERI; a Visiting Research Scholar in International Relations at LSE; a Brain Korea 21 Contract Professor at Seoul National University in Korea; and a Visiting Scholar at the I.E.C., Collège de France in Paris. She is a member of the CESE (Comparative Education Society in Europe) Executive Committee, and also serving as an international member of the 'Internationalisation Task Force' Committee within the AERA Higher Education Division. She is on the Executive Board of International Studies in Sociology of Education journal and also on the editorial board of the three international journals: Comparative Education, Intercultural Education, and Gender and Education. She has published one book and over 35 articles internationally in the field of higher education. Her research interests cover the following themes - international relations and the changing governance of higher education, knowledge, and the academic profession; academic migration and the knowledge economy, with special reference to Europe, North America and the Asia-Pacific countries. Many of her invitational writings and plenary talks have taken into account the future directions and strategic needs of Governments, international agencies, and policy think tanks.

Email: t.c.kim@uel.ac.uk 
Terri Kim (2014) The intellect, mobility and epistemic positioning in doing comparisons and

comparative education, Comparative Education, 50:1, 58-72, DOI: 10.1080/03050068.2013.874237

\title{
The Intellect, Mobility and Epistemic Positioning in doing Comparisons and Comparative Education
}

\author{
Terri Kim \\ University of East London
}

\section{Introduction}

Although there is a field of expertise entitled 'comparative education', comparative knowledge is not just understandable as the possession of compararivsits. Durkheim wrote: 'Comparative sociology is not a special branch of sociology; it is sociology itself' (1983, p. 157). C. Wright Mills also wrote: 'Comparisons are required in order to understand what may be the essential conditions of whatever we are trying to understand' (Mills, 1970, p. 163). Without necessarily invoking Durkheim or Mills, we do comparative analysis reflexively and much of works in intellectual history entail comparative inquiries.

From this starting point, this article is concerned with the aims and values of doing comparisons and comparative education. It reviews methodological nationalism agendas as the dominant epistemic positioning that has drawn the boundaries of doing comparative education. Using the concept of the 'gaze', it offers a reflexive analysis and discussion on the relationship between academic mobility and comparative knowledge creation. It argues what constitutes 'comparative knowledge' is not solely Wissenschaften (scientific knowledge) but more often entwined with Weltanschauungen (world view) derived from lived experiences. The paper reviews biographies of some of the major intellects whose mobile life courses have shaped the intellectual agendas for comparative knowledge creation, and reviews the concepts of the Other and Homeworld/Alienworld as epistemic positioning in doing comparative education.

In the framework of phenomenological thinking, the paper discusses the position of a 'stranger': the inside outsider or outsider within (Kim, 2009). This leads to a critical analysis of power embedded in forming and shaping new comparative knowledge to suggest that the intimate relationship between comparative knowledge and positional knowledge.

\section{Methodological agendas in comparative education}

Ever since I became a student of Comparative Education more than two decades ago, I have kept thinking about the ways in which our comparative knowledge is produced. This reflective inquiry has made me look at the specific relationship between Wissenschaft (scientific knowledge) and Weltanschauung (world view); and the relationship between homeworld (Heimwelt) and alienworld (Fremdwelt), in the framework of phenomenological thinking (Husserl; Steinbock, 1995).

In the field of comparative education, however, the connection between Wissenschaft and Weltanschauung (and between Hiemwelt and Fremdwelt) has too often been trapped in 'methodological nationalism' in the social sciences. The centrality of nation-states in comparative education is widely accepted. Historically, the genealogical roots of comparative education can be traced back to the 'modernist' epoch of the European Enlightenment of the late eighteenth and 
Terri Kim (2014) The intellect, mobility and epistemic positioning in doing comparisons and comparative education, Comparative Education, 50:1, 58-72, DOI: 10.1080/03050068.2013.874237

early nineteenth centuries (Kazamias, 2009). The conventional founding of 'modern' comparative education is often attributed to the writing of Marc-Antoine Jullien de Paris (1817) who had a very clear definition of usefulness: i.e. comparative education, as a positive science, will show the correct way to improve national education policy decisions (Fraser, 1964). Since the rise of romantic nationalism inspired by the ideas of Rouseau and Herder in 18th century Europe, the modern conceptions of nation-states became a collective delusion, which was based on the assumption that the nation-state is a natural social and political form of the modern world. In other words, the modern 'state' entered into a symbiotic relationship with the nationalist political project, which en passant framed our cognitive map in doing comparative education during the $19^{\text {th }}$ and $20^{\text {th }}$ centuries, within gradualist notions of social amelioration and the expansion of education. In the national framing of states and societies in the modern age, comparative education has been typically employing 'juxtaposition', 'similarities and differences', 'contexts', and ultimately 'learning from' other nations (Cowen, 2011). The title of Sadler's Lecture in 1900 captures the classic motifs of comparative education: "How far may we learn anything of practical value from the study of foreign systems of education?" (Sadler, 1900, in Higginson, 1979, p. 50). He claimed that: "The practical value of studying, in a right spirit and with scholarly accuracy, the working of foreign systems of education is that it will result in our being better fitted to study and to understand our own" (italics added; ibid).

In this way, everyday discourses and educational practices were structured and interpreted according to nation-state principles and became routinely assumed and 'banal' (Billig, 1995). In comparative education, this is also true; though the banality of nation-state as a unit of analysis cannot be just attributed to the early generation of comparative educationalists. Across disciplines in the social sciences, in general, methodological nationalism has continued to serve as a powerful invisible background to both empirical and epistemic worlds (Wimmer and Glick Schiller, 2002).

Over a long period of time comparative education gradually developed its own 'methods' literature and has diversified its analytic and epitemic agendas ${ }^{1}$, which has been extended into postmodern, post-positivist approaches ${ }^{2}$ in the broad domain of comparative education. The normative agendas of 'international development' with a vision of improving the world have also continued to intersect the field to establish 'international comparative education' institutionally, e.g. CIES and BAICE (Masemann, Bray and Manzon, 2007; Crossley, 2009; Unterhalter, 2009).

Overall, in terms of academic disciplinary formation, as investigated by Manzon (2011), comparative education has evolved into an inter-disciplinary subfield of educational studies, although it "has been constructed initially on the basis of strong institutional power albeit weak intellectual legitimacy" (Manzon, 2011, p. 101). She argues that structures of power that are external to comparative education have also influenced the history, borders, and definition of what is the field. Cowen (2003) captures such epistemic traditions and diverse agendas of comoparative education aesthetically in the following sentences:

\footnotetext{
${ }^{1}$ E.g research on education policy transfer (Phillip, 1989; Phillips \& Ochs, 2004; Phillips \& Schweisfurth, 2008); policy borrowing and lending (Steiner-Khamsi \& Waldow, 2012) and the new meta-theorization of transfer, translation and transformation (Cowen, 2006; 2009; 2013); and 'transitologies' (Cowen, 1999; 2013).

2 E.g. Postmodernism and Its Comparative Education Implications (Rust, 1991); Postpositivist Theorizing nd Research (Ninnes and Mehta, 2000; Unterhalter, 2009)
} 
Terri Kim (2014) The intellect, mobility and epistemic positioning in doing comparisons and comparative education, Comparative Education, 50:1, 58-72, DOI: 10.1080/03050068.2013.874237

As comparative educationalists, our attention flickers and we anguish about ourselves. We cannot make up our minds whether we are hygienic dissectors, like skilled fishmongers; agents of melioration - the politically alert plumbers of educational system improvement; or artistic empathisers, culturally-sensitive florists who examine the exotic in the world's educational gardens (Cowen, 2003a, p. 299).

However, Cowen (2006) also declares clearly what (academic) comparative education is not:

... comparative education as an academic subject does not fix educational things, when they are broken; it does not service the needs of Ministries of Education; it is not a branch of policy studies; it is not reducible to sociology, or to political science, or to history; it has not yet succumbed to the one true way of a specified methodology; nor has it accepted the seductive but corrosive position of claiming for itself disciplinary status in the terms defined so carefully by London philosophers of education... (Cowen, 2006, p. 570)

Contemporaneously, the multiple epistemological positionings in comparative education with a dilution in its intellectual identity and institutional status have increased complexity further given the new global contexts where trans-national and territorial cultures are entangled with one another in manifold ways and systemic measures for the international comparisons of educational outputs have become ever more routinized and assuming a new normative force such as OECD PISA. At the time of writing this article, the 2012 Program for International Student Assessment (PISA) results have been announced worldwide; and it is a high season for the comparative educationalists who are approached to provide instant comments on the PISA results in the media hype. PISA, administered every three years by the $O E C D$, measures performance on math, reading and science. It is designed to test whether students can apply what they have learned in school to real-life problems - i.e. 'problem-solving' skills. It was first run in 2000 and since then has rapidly become a strong governing technology, producing the world's most 'trusted' education league tables, with postulates and implications for all these 65 participating countries to base education reforms on them.

As Gita Steiner-Khamsi points out, "implicitly, the semantics of globalization promotes deterritorialization and de-contextualization of reform, and challenges the past conception of education as a culturally bounded system" (Steiner-Khamsi, 2004, p.5). Accordingly, comparison in itself has become a mode of governance (Nóvoa and Yariv-Masha, 2003; Rizvi and Lingard, 2009; Beach, 2009), governing narratives (Ozga, 2011) and global 'policyscapes' (Carney, 2012).

However, a decade ago, two missions of academic comparative education were proffered by Cowen (2004): "one is primarily to continue with theoretical comparative thinking. The other is to retain the tradition of 'comparative education' as a social movement, as a set of possibilities for action-on theworld, without the leftover vocabularies of colonialism, neo-colonialism, aid and development and so on." (Cowen, 2006, p. 570).

But what are we actually trying to understand? He continues to suggest a permanent academic agenda in doing comparative education that is to understand the intersection of international and domestic politics as they shape 'educational systems' and the compression of social power into educational forms - something that is made real for us in individual biographies and educated 
Terri Kim (2014) The intellect, mobility and epistemic positioning in doing comparisons and comparative education, Comparative Education, 50:1, 58-72, DOI: 10.1080/03050068.2013.874237

identities. "Understanding those processes would permit us to speak truth unto the State; and a few other people as well." (Cowen, 2009, pp. 1287-1291).

Following this line of comparative education tradition and mission in my academic journey, the second theme that has kept my attention is 'positioning', which is crucial in the process of comparative meaning-making and new knowledge creation, as things can (and do) exist independent of our knowledge of them.

\section{Positioning in comparative knowledge creation: the 'gaze'}

I employ the concept of the 'gaze' here as a means to understand 'positioning' in the process of comparative knowledge creation. In Las Meninas in The Order of Things (1970), Michel Foucault examined the peculiar function of the gaze, and argued that the ensuing relationship between the gaze of the spectator and the gaze of the painting break down the usual binary nature of the gaze: i.e. between a viewer-gaze and a viewed-gaze (Foucault, 1970). This implies the positioning becomes a 'relationship' in which someone enters. In this regard, Jean Paul Sartre saw the gaze as the battleground for the self to define and redefine itself. The gaze of the 'Other' is outside our immediate control and the way the gaze objectifies us robs us of our freedom as a subject: "insofar as I am the object of values which come to qualify me without my being able to act on this qualification or even to know it, I am enslaved."(Sartre, 1956, p. 110; Re-quoted from http://lucian.uchicago.edu/blogs/mediatheory/keywords/gaze/).

Foucault extends this almost paranoid notion of the gaze into the realm of surveillance, arguing that the gaze becomes the perfect medium for spreading domination. In The Birth of the Clinic (Naissance de la clinique: Une archéologie du regard medical, 1963), Foucault noted the gaze becomes the "speaking eye" that surveys and describes everything at the level of medicine; the eye becomes the "depository and source of clarity," equated with knowledge, which in turn is equated with power ${ }^{3}$ (Foucault, 1973, p. 114). The medical gaze is then extended to power relations. Lacan also took his position on the gaze as he developed his theories in psychoanalysis. Lacan's notion of the gaze is not just a seen-gaze but also a gaze-imagined in the field of 'the Other'. The gaze becomes the medium for self-differentiation (Lacan, 1978). Accordingly, in the gaze, there is never the Other in and of itself. The Other is always relative, as determined by the gaze, the way in which he/she is accessed.

The paradoxical form of the Other is suggested by Husserl as "the verifiable accessibility of what is not originally accessible" (Husserl, 1960, p. 114). The Other is then established through a kind of order that determines what is 'inside' and what is 'outside' and contributes the meanings of the

\footnotetext{
${ }^{3}$ Foucault's intellectual project was to analyse the longue durée of formation and use of these discourses within the context of specific historical practices. In The Order of Things (Les Mots et les choses) published three years later in 1966, Foucault presented a comparative study of the development of economics, the natural sciences and linguistics in the 18th and 19th centuries, which can be claimed as the first 'postmodern' history of ideas. Foucault wrote his next major work, The Archaeology of Knowledge (L'Archéologie du Savior) during the period of residing in Tunisia (1966-68). This period of writing was a turbulent time for Tunisia with serious political violence and demonstrations aimed primarily at Israel. It is said that Foucault's experience in Tunisia had an effect on his work and thought. In the Archaeology of Knowledge, Foucault argued that in addition to the classical unities of the existing human sciences, there are discursive unities that underlie them and are often not evident (Biography of Michele Foucault, The Foucault Society, 2010:

http://foucaultsociety.wordpress.com/about-michel-foucault/).
} 
Terri Kim (2014) The intellect, mobility and epistemic positioning in doing comparisons and comparative education, Comparative Education, 50:1, 58-72, DOI: 10.1080/03050068.2013.874237

Other as 'the elsewhere itself' (by Merleau-Ponty) or 'lively absence' (by Waldenfels). The Other is like memory, retaining its impact on the present (Waldenfels, 2007). Likewise, the homeworld is in some mode of lived mutuality with the alienworld - the world of difference and otherness (Steinbock 1995, 178-85). 'The past is a foreign country' (the title of Lowenthal's (1985) tome) is a useful trope that resonates with the relationships as such, which I think have significant epistemic implications for comparative educationalists. John Urry also used the concept of the gaze in the realm of tourism, asserting that "To be a tourist is one of the characteristics of the 'modern' experience" (Urry, 2002).

Overall, all these theories of spectatorship, the gaze and the analyses of its entailed implicit power relations made me think about a specific 'comparative' gaze in doing comparative education, especially in relation to my research inquiries of a specific relationship between academic mobility and new knowledge creation. Academic mobility in that sense cannot just be regarded as a simple physical movement from one place to another. It can be 'secular pilgrimage' - referring to Rupert Sheldrake's metaphor here (Urry, 2002, p. 4). Academic mobility proffers the accumulation of grace by visiting the shrines of high academic culture and sacred centres of learning, and also by cultivating what Honore de Balzac called "the gastronomy of the eye", from which one can derive a new 'comparative gaze'.

Academic travels have always been regarded important among intellectual elites, let alone educationalists with particular aims and uses of comparative inquiries about 'foreign worlds and educations'. Even before the time of Jullien de Paris of 1817, the typical 18th-century sentiment was that of the studious observer traveling through foreign lands reporting his findings on human nature for those unfortunate enough to have stayed home. Foreign travels were considered an inherent part 'to complete the education of an English gentleman' (Shackleton, 1971). ${ }^{4}$ What was then named the 'Grand Tour' was a phenomenon which shaped the creative and intellectual sensibilities of some of the eighteenth century's greatest artists, writers and thinkers. In other words, foreign travels provided a comparative 'gaze' for both young and established scholars with power networks in both political and intellectual circles of the time.

Adam Smith, for instance, derived much personal philosophical benefit and comparative knowledge creation from the period of journeying on continental Europe. When Smith travelled the Continent as a tutor with his pupil, the young Duke of Buccleuch in 1763, he met Voltaire in Geneva and spent almost a year in Paris, where he discussed political economy with the French Ministers, Turgot and Necker and various luminaries of the thriving circle of philosophies, including Quesnay, a French economist of the Physiocratic School and also a court physician (Elliott, 1990, p. 10). Adam Smith, was exposed to both the English and French political-economic systems of the day; and it was during the time in France that Adam Smith began to write his magnum opus, which he continued to write on his return to Kirkcaldy. Smith devoted himself deeply to his inquiry into the nature and causes of national wealth and it took Adam Smith ten years to dictate and edit The Wealth of Nations (1776), which was conceived as a sequel to The Theory of Moral Sentiments (1759), for he never ceased

\footnotetext{
${ }^{4}$ For details, see Robert Shackleton, 'The Grand Tour in the Eighteenth Century' In Louis T. Milic (ed). Studies in Eighteenth Century Culture 1 (Cleveland: The Press of Case Western Reserve University, 1971).
} 
Terri Kim (2014) The intellect, mobility and epistemic positioning in doing comparisons and comparative education, Comparative Education, 50:1, 58-72, DOI: 10.1080/03050068.2013.874237

analysing human behaviour and moral obligations. ${ }^{5} \mathrm{He}$ had often discussed it in Edinburgh, often with David Hume, often in London and France. He proceeded to dictate his masterpiece, slowly, haltingly, breaking off from time to time to travel down to London to consult others on special problems. ${ }^{6}$ Benjamin Franklin, for instance, provided valuable information about the economy and trade of colonies (Viner,1937) for Adam Smith's comparative knowledge and 'vent-for-surplus' theory of international trade.

As such a specific comparative gaze taken by an itinerant academic would result in a particular interpretation and theorisation of comparative inquiries. In other words, it can be suggested that mobility affects our positioning and cultivates new perspectives through the comparative 'gaze' taken - both seen and imagined. Highly mobile academics - as I examined in my biographic narrative research on 'mobile academics and knowledge creation' (which received a SRHE Research Award, 2011-12) - have all engaged in taking a comparative 'gaze' in the course of encountering and crossing 'boundaries' - both empirical and epistemic, which accompanies 'voluntary' and 'involuntary' displacement experiences.

\section{Methodological clarification of my research analysis}

As a mobile academic, comparative educationalist myself, I have always been interested in the relationship between academic mobility and comparative knowledge creation. My biographic narrative analysis takes a phenomenological approach - as an instance of 're-living' rather than 'reporting' (Madison, 2010, p. 65), concerned with the experience and perspective of the individual, 'bracketing' taken-for-granted assumptions and conventional ways of perceiving. In this regard, Max van Manen reminds us of phenomenology as an experience of humility and depth - combining hermeneutics and inter-subjective heuristics. He warns us that if research writing is conceived as a reporting process, imbued with values of methodological objectivity, we may lose the nuanced fecundity of qualitative insight. Accordingly, 'method can become a 'law' and the work sterile, method can kill a piece of qualitative research' (van Manen, 1997, p. 125; recited from Madison, 2010, p. 65).

Given the phenomenological standpoint, my analytic frame of reference draws on C. Wright Mills' Sociological Imagination and Paul Ricoeur's Time and Narrative and Narrative Identity to delineate the intricate connection between the patterns of individual lives and social structures and movements and the course of world history in an attempt to "understand the larger historical scene in terms of its meaning for the inner life and the external career of a variety of individuals." (Mills, 1959, p. 5). Thus, historical time becomes human time "to the extent that it is articulated through a

\footnotetext{
${ }^{5}$ Adam Smith wrote his "economics" as part of his work as a philosopher. He was the Chair Professor of Moral Philosophy at the University of Glasgow. (In the days of Adam Smith, much of the study carried out at universities was history and philosophy; a course in philosophy would include a study of jurisprudence. A study of justice leads naturally to a study of the various legal systems, which of course leads to the study of government, and, finally, to a study of political economy (http://martinfrost.ws/htmlfiles/adam smith.html). ${ }^{6}$ Dugald Stewart states that Hume wrote out his books with his own hand, and Adam Smith dictated his to a secretary. (Account of the Life and Writings of Adam Smith LL.D. by Dugald Stewart, 1793, from the Transactions of the Royal Society of Edinburgh. Read by Mr Stewart, January 21, and March 18, 1793. Printed in the Collected Works of Dugald Stewart, vol. 10, pp. 1-98 (http://www.adamsmith.org/sites/default/files/resources/dugald-stewart-bio.pdf).
} 
Terri Kim (2014) The intellect, mobility and epistemic positioning in doing comparisons and comparative education, Comparative Education, 50:1, 58-72, DOI: 10.1080/03050068.2013.874237

narrative mode, and narrative attains its full significance when it becomes a condition of temporal existence." (Ricoeur, 1984, p. 52).

\section{Homo Viator: exemplary comparativists}

Academic mobility constitutes an intrinsic professional identity of comparativists. We are homo viator - itinerant men and women in perpetual (academic) pilgrim condition both in real life and metaphorically. Many of the early generation comparative educaionalists were notably transnational, either as émigré scholars or with immigrant family backgrounds - e.g. Robert Ulich (German émigré scholar), Nicolas Hans (Russian émigré scholar), Joseph Lauwerys (Belgian British) and George Bereday (Polish American). Here, I would take Robert Ulich's biography and life history as an exemplary émigré comparativist, whose scholarship in comparative education illustrates the very intrinsic relationship between Wissenschaft and Weltanschauung. The following summary of Robert Ulich's biography is mainly depicted from Harvard Square Library online sources (http://www.harvardsquarelibrary.org/unitarians/ulich.html). 
Terri Kim (2014) The intellect, mobility and epistemic positioning in doing comparisons and comparative education, Comparative Education, 50:1, 58-72, DOI: 10.1080/03050068.2013.874237

Robert Ulich (1890-1977) was "a professor of the history and philosophy of education at Harvard University from 1935 until 1960. During those years, he published ten books whose subjects ranged from comparative education to the history of educational thought to his own philosophy of self-transcendence outlined in his best known book, The Human Career. Born in Bavaria to a family with a long tradition of religious and contemplative thinkers, Ulich entered the Humanistisches Gymnasium at the age of 9. Over the course of the following decade, he was educated in the Classics as well as English, French and Hebrew. Ulich's classical studies provided him with a profound sense of Western history which proved critical to his academic career. His broad interests and unending curiosity made it difficult for him to specialize until he had a brief but defining experience working in a metal plant. Observing the misery of his working-class colleagues, he conceived of an education that must accommodate the basic human desire for progress and happiness, an education that is commensurate with the dynamics of the society in transformation. Although Ulich's works published during the first two decades of his career are slim in contrast to his later prodigious outpouring, two works published during this era suggest the direction of his later research. Dietmar Waterkamp (1997) has noted that these works demonstrate his ability to analyze the social and political tendencies of the present epoch by comparing them with similar constellations in history. Neither work bore any relation to education.

In 1933, in response to a group firing of colleagues at the Dresden Institute of Technology who were described as "racially and politically undesirable", Ulich resigned both his professorship there and his position with the Ministry of Education of Saxony. He could easily have been arrested for this act of protest, but his wife's high social standing protected him. Soon after his resignation Ulich was offered a one year position as lecturer in comparative education at the Harvard Graduate School of Education. The lectureship rescued Ulich from an increasingly dangerous political climate in Germany. In 1934, Ulich, a 44-year old and seasoned academic scholar and administrator arrived at Harvard. After one year, Ulich was appointed Professor of the History and Philosophy of Education and was soon naturalized as a U.S. citizen.

There is little question that the tragic rise of the Nazi party in Germany, whose ultimate aims Ulich foresaw with uncommon clarity, shaped his approach to educational philosophy. Ulich wrote, "Nothing is more dangerous to mankind than the divine gift of faith uncontrolled by the equally divine gift of reason."

As remarked by Francis Keppel, who served as Dean of Harvard's Graduate School of Education at the time of Ulich's 1960 retirement from the faculty, Ulich's departure from Germany in 1933 was not caused by academic ambition. It was rather a magnificent protest against a way of life he could not approve. It was an act of personal courage and intellectual honesty. Once arrived in the United States, he did not take the easier path for which his academic training had fitted him. He joined the faculty of a School of Education, well knowing that it was neither fashionable nor an easy road for a new citizen.

His rich historical knowledge and philosophical training set him apart from most educational thinkers at work in the United States. Education, wrote Ulich, was a long enduring process of cultural self-evolution in which we must discover ourselves as part of a reality that is creative and whose power compels a cosmic reverence. His thinking reflected a secular religiousness. As Ulich 
Terri Kim (2014) The intellect, mobility and epistemic positioning in doing comparisons and comparative education, Comparative Education, 50:1, 58-72, DOI: 10.1080/03050068.2013.874237

explained, "The most radical and comprehensive thinking leads a person beyond the boundaries of the merely empirical and rational into the sphere of the mysterious."

Waterkamp (1997) explains that Ulich's religiousness was a spirituality and a belief in belonging to a cosmic totality with no specified contents of belief and an aversion to every dogmatism. This belief may have been nourished by his friendship with Paul Tillich, whom he first met at the Dresden Institute of Technology and knew later when both men were at Harvard University. His philosophy of self-transcendence conformed with the Unitarian faith to which he and one of his favorite educational philosophers, Thomas Jefferson, belonged.

As a scholar of comparative education, Ulich analysed the American school system. In his 1951 book, Crisis and Hope in American Education, Ulich outlined the weaknesses of the current system, mentioning as key factors in its failure "the lack of a coherent curriculum in schools and undergraduate studies, the rule of the credit-system, the widespread application of tests, the broad range of choice for the students-which allowed the avoidance of intellectually demanding courses and impeded coherent and sequential learning - the lack of selection in schools and undergraduate studies, and the clinging to a 'single-ladder' school system." (Waterkamp, 1997). His preferred model for the U.S. educational system has been described as elitist in that it fell in line with fellow Unitarian Thomas Jefferson's belief in a "natural aristocracy among men." Waterkamp (1997) explains that "it set up a typology of talents in relation to societal needs as a basis for establishing a selective school system." In such a system, the two social classes would share a mutual understanding, if unequal educational opportunities. Social mobility ought to be a slow process, according to Ulich, in order to prevent "the half-education of the Hitler type" and "an uprooted and unemployed academic proletariat of the Goebbels type." In 1954, Ulich's prolific contributions to the fields of the history of education, philosophy of education, and comparative education were recognized with his appointment to the first James Bryant Conant Professorship at Harvard University. He retired from teaching in 1960 and returned to Germany in 1970.

The fact that Ulich's name and philosophy are not commonly known in education today may be related to his intellectual aims for education which resisted concretization. He did not focus his energies on a dissection of the American system or on the creation of methodology, but strove instead to persuade educational leaders to think critically about educational problems within a historical and philosophical framework. One might have thought then that Robert Ulich would champion the pure tradition of German intellectualism, since a perversion of it was itself in part responsible for some of the tragedies of his own life. Or he might have reacted, as so many have done, by taking the leadership in expounding the popular educational philosophy of the day in America. Characteristically, he did not. He ever sought the strength of both traditions, and struggled to rid them of their weaknesses. He soon found in the America of the 1930s and 1940s that he walked a lonely road." (Harvard Alumni Bulletin

1977: http://www.harvardsquarelibrary.org/unitarians/ulich.html)

Overall, my research, using biographical accounts of distinguished trans-national academic intellectuals, has focused on how mobility has led to a new mode of knowledge creation in the process of becoming 'strangers' and being positioned as academic migrants. The biographies of the selected mobile academics whose knowledge have become transnational tell us that the whole set 
Terri Kim (2014) The intellect, mobility and epistemic positioning in doing comparisons and comparative education, Comparative Education, 50:1, 58-72, DOI: 10.1080/03050068.2013.874237

of mobility-related experiences - the initial act of crossing territorial boundaries, settling in and adaptation to a new (academic) milieu are entwined with the process of epistemic transformation. 'Displacement' is a common experience of most migrants, but for some academics, if not many, such experience has led to a new breakthrough and paradigm shifting knowledge creation.

Zygmunt Bauman, a renowned Polish academic émigré in Britain since 1971 and one of the most prominent academic intellectuals of our time, confirms his ontological position as a 'stranger' here: "I used to be earlier a citizen of Poland, but my citizenship was later withdrawn. I found refuge in England, but I was only adopted by that country. Here and there, I am a "bloody foreigner"... (laughs). (JDC International Centre for Community Development, 'Interview with Zygmunt Bauman': http://www.jdc-iccd.org/en/article/42/interview-with-zygmunt-bauman).

Among the mobile academic intellectuals whose academic biographies and life histories I examined, there was a considerable difference in the way the host country was perceived between those enthusiastically welcomed in academic society and those who had to depend, initially, on their own resources. Norbert Elias's biography belongs to the latter case. Norbert Elias's personal biography and his sociological theory came nowhere nearer convergence than in his propositions about 'established-outsiders' relationships.

\section{Significance of marginality in knowledge creation}

With his first-hand experience of the First World War as a soldier in the German army and the subsequent social disorder in the Weimar period and the murderous nature of the Nazi regime, Elias analysed The Civilizing Process $(1969 ; 1982)$ as a specific transformation of human behaviour. Even after he escaped the Nazi Germany, however, his career as an academic émigré was unusual and difficult.

Elias (1897-1990) initially studied both medicine and philosophy in Breslau and later sociology in Heidelberg where he learned from Karl Jaspers and did Habilitation under Alfred Weber (the brother of Max Weber). In 1930 Elias chose to follow Karl Mannheim to become his assistant in Frankfurt. After the Nazi take-over in 1933, Mannheim's sociological institute was forced to close and Elias fled to Paris. In Paris, although he was soon able to move into French intellectual circles, there was no prospect of academic employment in France. After two years in poverty in Paris, he moved to London, accepting the invitation from Karl Mannheim who was already at LSE. Elias was thirty-eight years old then, had published very little, and did not speak English. Therefore, his career prospects in Britain were also very limited. Whilst working as Senior Research Assistant to Karl Manheim at LSE, he completed the two volumes of his magnum opus, The Civilizing Process (Über den Prozeß der Zivilisation, 1939). Elias argues that the process of civilization in not linear and consistent. The multiplicity of social groups, as well as the varying and uneven sources of change, have created a variety of social behaviors and formations. However Elias does not see this as a source of legitimate social heterogeneity but rather a different phases in the course of the hegemonic formation of the western habitus. These large scale and broad processes, Elias explains, have permeated into the consciousness of the individual. Elias terms this process as "sociogenetic". The civilizing process described by Elias is a constant process of self restraint and impulse management that were developed and 
Terri Kim (2014) The intellect, mobility and epistemic positioning in doing comparisons and comparative education, Comparative Education, 50:1, 58-72, DOI: 10.1080/03050068.2013.874237

established since the 16th century and that were eventually spread world-wide (Elias, 1969; 1982; 2000).

When the German invasion of Britain appeared imminent in 1940, Elias was detained at internment camps on account of his being German, even though he was a Jewish academic émigré. After his release in 1941, he taught evening classes in an adult learning organisation in Cambridge, and towards the end of the war, Elias also worked for British intelligence. It was only 1954 that Elias had the first secure academic post at the University of Leicester, Sociology Department. He was then 57 years old. And it was only in his late seventies and his eighties that Elias came at last to be regarded by many social scientists as having 'one of the world's most original and penetrating sociological thinkers.' (Mennell and Goudsblom,1998).

Elias's biography suggests that critical incidents in his lifetime and the experiences of crossing boundaries - epistemic, academic culture, and territorial boundaries have intimately interwoven and led to new knowledge creation. Elias' writing reflects his powerful sympathy for outsiders of every kind, and in retrospect, Elias remarked that personal experiences and the events of his time, influenced his thinking at least as much as any book he read (ibid).

As exemplified in Elias' life and scholarship, what academics carry is not just expertise (knowledge as science) but also a mode of thinking - the overall orientation toward the structures of meaning (Gouldner 1979; Hannerz 1990). They are engaged in reflexive knowledge creation. Their world views derived from lived experiences (Weltanschauungen) are an integral part of their knowledge creation (Wissenschaften).

There are some common characteristics of transnational mobile academics and their mode of knowledge creation, as examined in my SRHE research (Kim \& Brooks, 2013). For instance, academics become mobile through discipline-based networks. Secondly, mobile academics in crossing many borders and boundaries often assume the role of inter-national 'knowledge broker', 'knowledge trader' as well as become institutionalised 'local career adapter'. And thirdly, mobile academics tend to employ interdisciplinary, comparative approaches.

In terms of new comparative knowledge creation, however, I would stress the importance of 'nomadic imagination' exercised by free floating thinkers in pursuit of intellectual emancipation through knowledge creation, which is transcending the territorial confinement of knowledge bound to the nation-state as a unit of analysis. The biographies and life histories of Robert Ulich and Norbert Elias illustrated above confirm this epistemic positioning.

\section{Position of a 'stranger': becoming a trans-national comparativist}

Further, I would suggest that this is possible by assuming the position of a 'stranger' (invoking Simmel), or the 'consecrated heretic' (invoking Bourdieu). Simmel confirms that "to be a stranger is naturally a very positive relation... It is a specific form of interaction... He [the stranger] is not radically committed to the unique ingredients and peculiar tendencies of the group, and therefore approaches them with the specific attitude of 'objectivity'. Objective here, according to Simmel, is a 
Terri Kim (2014) The intellect, mobility and epistemic positioning in doing comparisons and comparative education, Comparative Education, 50:1, 58-72, DOI: 10.1080/03050068.2013.874237

"particular structure composed of distance and nearness, indifference and involvement." (Simmel, 1908; Wolff, trans. Ed. 1950, pp. 402-408).

I argue that becoming a trans-national comparativist is like assuming the position of a stranger - as conceptualised by Georg Simmel: "His position within it, is fundamentally affected by the fact that, he does not belong in it initially, and that he brings qualities into it, that are not, and cannot be, indigenous to it." (ibid).

Also, the description of 'consecrated heretics' in Pierre Bourdieu's book, Homo Academicus (1988) matches the importance of marginality that I consider an attribute to comparative knowledge creation, which I have found often among trans-national academic intellectuals.

... even when they are not entirely estranged from the 'normal' career pattern - as is the case with those of them who were not born in France, without being totally alienated from the university order, they [transnational academic intellectuals] are often those who have accomplished a more or less decisive detour from the 'normal' trajectories which lead to simple reproduction and from the psychological and social security which these trajectories guarantee (Bourdieu, Homo Academicus, 1988, p. 107).

Drawing upon the sociology of Georg Simmel and the philosophy of Jacques Derrida, Bauman (1991) also discussed the position of a 'stranger' who is present yet unfamiliar, society's undecidable. In Bauman's analysis, the Jews became 'strangers' par excellence in European history. In Modernity and the Holocaust, Bauman (1989) argued that the Holocaust should not simply be considered to be an event in Jewish history, nor a regression to pre-modern barbarism. Rather, he argued, the Holocaust should be seen as deeply connected to 'modernity' and its order-making efforts - procedural rationality, taxonomic categorisation, and the tendency to view rule-following as morally good. Similarly, Bernhard Waldenfels (1997) also suggested in his Topography of the Alien [Topographie des Fremden] that modern Europeans used to assume "the standpoint of universality" but they blindly turned it into "the universal standpoint". The latter standpoint/positioning leads to the "pressure of universalization", which pushes the self and the other under its compulsion (Waldenfels, 1997; Re-quoted from Yu, 2005, p. 29).

\section{Dénouement}

As reviewed earlier, the geneaology of comparative education entails the ideology of usefulness framed by methodological nationalism, which "has helped to permit a whole range of intellectual, quasi-intellectual, and rather practical activities to be gathered together under the umbrella name, 'comparative education' to the point where serious epistemological, ethical and political confusions are occurring" (Cowen, 2006, p. 561). There are many versions of comparative education after all, as Cowen (2009) pinpoints that "what we call comparative education, in its growth, in its shapeshifting, is itself part of international, political, economic, cultural and educational relations" (Cowen, 2009, p. 1289).

Contemporaneously, in the age of academic mobility and migration, comparative research involves crossing and bridging boundaries more frequently than ever before, and boundaries are suddenly being an idea itself at the centre of a number of 'comparative' fields. In this regard, it is suggested 
Terri Kim (2014) The intellect, mobility and epistemic positioning in doing comparisons and comparative education, Comparative Education, 50:1, 58-72, DOI: 10.1080/03050068.2013.874237

that mobile academic comparativists should take on the position of a 'stranger' and their embodied travelled knowledge reflects the notion of a dialectical third, which creatively especapes from the binary division between the Homeworld and Alienworld in the framework of phenomenological comparative thinking.

Meanwhile, the global expansion of neoliberal market-framed university regimes may indicate what used to be the idiosyncrasies of 'colonial' higher education - which I depict as 'pragmatic' and 'problem-solving' approaches to knowledge - has become a global trend contemporaneously. Such trends leave very little space for free floating mobile academic intellectuals as comparativists, whose positions as an inside outsider, or outsider within, and whose work produces new comparative knowledge.

Daniel H. Pink agues, in his recent book To Sell is Human (2012), that the premium has already moved from 'problem solving' to 'problem finding' as a 'skill' in the business world. School superintendents rated problem-solving as the top capability they wanted to instill, whereas corporate executives rated problem-solving as seventh on their list of attributes in employees, but rated problem identification as the single most important skill. Pink says, "Right now, especially in the commercial world, if I know exactly what my problem is, I can find the solution to my own problem. I don't need someone to help me. Where I need help is when I don't know what my problem is or when I'm wrong about what my problem is. Problem solving is an analytical, deductive kind of skill. The phrase 'problem finding' comes out of research on artists. It's more of a conceptual kind of skill." (Rose, 13 January 2013). I would suggest the same logic could be applied to a role of mobile academic intellectuals as the Schumpeterian entrepreneur (Schumpeter, 1934; 2008) in the world of comparative education. For many of us as mobile academics engaged in comparative knowledge creation, problem-finding would be a more appropriate job than problem-solving, especially nowadays as education itself is on the verge of a new paradigm shift. We can leave the old mantras of comparative education now.

\section{References}

Bauman, Z. (1989) Modernity and the Holocaust, Ithaca, NY: Cornell University Press.

Bauman, Z. (1991) Modernity and Ambivalence, Ithaca, NY: Cornell University Press.

Beech, J. (2009) Who is strolling through the global garden? International agencies and educational transfer In Cowen, R. and Kazamias, A. (2009) International Handbook of Comparative Education, Springer, pp. 341-358.

Billig, M. (1995) Banal Nationalism. London: Sage Publications.

Carney, S. (2012) Imagining Globalisation: Educational Policyscapes In Steiner-Khamsi, G. and Waldow, F. (Eds). Policy Borrowing and Lending in Education, World Yearbook of Education 2012, Abingdon, Oxon and New York: Rougledge, pp. 338-353. 
Terri Kim (2014) The intellect, mobility and epistemic positioning in doing comparisons and comparative education, Comparative Education, 50:1, 58-72, DOI: 10.1080/03050068.2013.874237

Cowen, R. (2012) Robustly Researching the Relevant: A Note o Creation Myth in Comparative Education In Lennart, W., Gustafsson, C., and Riis, U. (Eds). (2012). Op. cit., pp. 3-26.

Cowen, R. (2011) Edging Closer to the Hero, the Barbarian, and the Stranger In Daniel Tröhler, D. and Barbu, R. (Eds). Education Systems in Historical,Cultural, and Sociological Perspectives, The Future of Education Research Volume 1, pp 21-36.

Cowen, R. (2009) Then and Now: Unit Ideas and Comparative Education In Cowen, R. and A. Kazamias (eds). International Handbook of Comparative Education, Springer, pp. 1277-1294.

Cowen, R. (2006) Acting comparatively upon the educational world: puzzles and possibilities In Oxford Review of Education, Vol. 32,No. 5, p. 561-573.

Cowen, R. (2003). Agendas of Attention: a response to Ninnes and Burnett, Comparative Education 39 (3), 299-302.

Cowen, R. (1999). 'Late Modernity and the Rules of Chaos: an initial note on transitologies and rims' in R. Alexander, P. Broadfoot, D. Phillips (Eds.) Learning from Comparing New Directions in Comparative Educational Research, Vol.1, Contexts, Classrooms and Outcomes, Oxford: Symposium Books.

Crossley, M. (2009) Rethinking Context in Comparative Education In Cowen,R. and Kazamias (eds). International Handbook of Comparative Education, Springer, pp. 1173-1187.

Durkheim, E. (1982) The Rules of Sociological Method, London and Bashingstoke: Macmillan.

Elias, N. (1969) The Civilizing Process, Vol.I. The History of Manners, Oxford: Blackwell.

Elias, N. (1982) The Civilizing Process, Vol.Il. State Formation and Civilization, Oxford: Blackwell.

Elias. N. (2000) The Civilizing Process. Sociogenetic and Psychogenetic Investigations. Revised edition. Oxford: Blackwell.

Elliott, N. (Ed.) (1990) Adam Smith's Legacy, London: Adam Smith Institute.

Foucault, M. (1973). Seeing and Knowing In The Birth of the Clinic: An Archaeology of Medical Perception. New York: Pantheon Books.

Foucault Society (2010) Biography of Michele

Foucault: http://foucaultsociety.wordpress.com/about-michel-foucault/.

Fraser, S. (1964). Jullien's Plan for Comparative Education 1816-1817. Teachers College, Columbia University: Bureau of Publications.

Gouldner, A. (1979). The future of the intellectuals and the rise of the new class. London: Macmillan. 
Terri Kim (2014) The intellect, mobility and epistemic positioning in doing comparisons and comparative education, Comparative Education, 50:1, 58-72, DOI: 10.1080/03050068.2013.874237

Hannerz, U. (1990). Cosmopolitans and locals in world culture. In Theory, Culture \& Society, 7, pp. 237-251.

Higginson, J.H. (Ed.) (1979). Selections from Michael Sadler: Studies in world citizenship. Liverpool: Dejall \& Meyorre.

Husserl, E. (1960) Cartesian Meditations: an introduction to phenomenology. Trans. Dorion Cairns. M. Nijhoff: The Hague.

Kazamias, A. (2009) Comparative Education: Historical Reflections In Cowen, R. and Kazamias, A. (eds). Op. cit., pp. 139-157.

Kelly, C. (1997) A Grand Tour: Reading Gibbon's Decline and Fall In Greece \& Rome, Vol. 44, No. 1, pp. 39-58.

Kim, T. (2010) Transnational Academic Mobility, Knowledge and Identity Capital In Discourse: Studies in the Cultural Politics of Education. Special Issue on International Academic Mobility. Edited by Johannah Fahey and Jane Kenway. 31(5), pp. 577-592.

Kim, T. \& Brooks, R. (2013) Internationalisation, Mobile Academics, and Knowledge Creation in Universities: a Comparative Analysis. SRHE Research Award (2011/12) Final Report.

Lacan, J. (1978). Four Fundamental Concepts in Psychoanalysis, ed. Jacques-Alain Miller and trans. Alan Sheridan. New York: Norton.

Larsen, M. (Ed.). (2010b). New thinking in comparative education: Honouring the work of Robert Cowen. Rotterdam: Sense Publishers.

Lennart, W., Gustafsson, C., and Riis, U. (Eds). (2012) Enlightenment, Creativity and Education: Polities, Politics, Peformances, Rotterdam: Sense Publishers.

Manzon, M. (2011). Comparative Education: The Construction of a Field. Hong Kong: Comparative Education Research Centre, The University of Hong Kong \& Springer.

Masemann, V., Bray, M. and Manzon, M. (eds) Common Interests, Uncommon Goals: Histories of the World Council of Comparative Education Societies. Hong Kong: CERC, 2007.

Mennell, S. and Goudsblom, J. (eds) (1998) Norbert Elias: on Civilization, Power and Knowledge, Selected Writings, University of Chicago, 1998.

Mills, C. Wight (1970) Sociological Imagination, Harmondsworth: Penguin.

Ninnes, P. and Mehta, S. (2000) Postpositivist Theorizing and Research: Challenges and Opportunities for Comparative Education In Comparative Education Review, Vol. 44, No. 2 (May), pp. 205-212. 
Terri Kim (2014) The intellect, mobility and epistemic positioning in doing comparisons and comparative education, Comparative Education, 50:1, 58-72, DOI: 10.1080/03050068.2013.874237

Nóvoa, A. and Yariv-Mashal, T. (2003). Comparative Research in Education: a mode of governance or a historical journey In Comparative Education, Vol 39, No.4, pp 423-438.

Ozga, J. (2011) Governing Narratives: "local" meanings and globalising education policy In Education Inquiry, Vol. 2, No. 2, May 2011, pp.305-318.

Phillips, D. (1989). Neither a borrower nor a lender be? The problems of cross-national attraction in education. Cross-National Attraction in Education, Special Issue, Comparative Education, Vol. 25, No. 3, pp. 267-274.

Phillips, D. and K. Ochs (Eds.) (2004). Educational Policy Borrowing: Historical Perspectives. Oxford Studies in Comparative Education. Oxford: Symposium Books.

Phillips, D. and Schweisfurth, M. (2008). Comparative and International Education: An Introduction to Theory, Method and Practice, London: Continuum.

Pink, D. H. (2012) To Sell is Human, New York: Riverheads Books (Published by the Penguin Group).

Ricoeur, P. (1983) Temps et récit, Paris: Editions du Seuil; (1984) Time and Narrative vol. 1, trans. by Kathleen McLaughlin and David Pellauer, Chicago: University of Chicago Press.

Rizvi, F. and Lingard, B. (2009) The OECD and Global Shifts in Education Policy In Cowen, R. and Kazamias (Eds). Op. cit.

Rust, V. (1991) Postmodernism and Its Comparative Education Implications In Comparative Education Review, Vol. 35, No. 4 (November), pp. 610-626.

Sadler, M. (1900). 'How far can we learn anything of practical value from the study of foreign systems of education?' Address of 20 October. In Higginson, J. H. (Ed). Selections from Michael Sadler (pp.48-51). Liverpool: Dejall \& Meyorre.

Schumpeter, J.A., 1934 (2008), The Theory of Economic Development: An Inquiry into Profits, Capital, Credit, Interest and the Business Cycle, translated from the German by Redvers Opie, New Brunswick (U.S.A) and London (U.K.): Transaction Publishers.

Shackleton, R. (1971) 'The Grand Tour in the Eighteenth Century' In Louis T. Milic (ed). Studies in Eighteenth Century Culture 1, Cleveland: The Press of Case Western Reserve University.

Simmel, G. (1971). Georg Simmel on individuality and social forms: Selected writings (D.N. Levine, Ed. and Intro.). Chicago: The University of Chicago Press.

Steinbock, A. (1993). Homeworld/alienworld: Towards a Generative Phenomenology. Front Cover. Anthony Joseph Steinbock. State University of New York at Stony Brook.

Steiner-Khamsi, G. (Ed). (2004). Lessons from Elsewhere: The Politics of Educational Borrowing \& Lending. New York: Teachers College Press. 
Terri Kim (2014) The intellect, mobility and epistemic positioning in doing comparisons and comparative education, Comparative Education, 50:1, 58-72, DOI: 10.1080/03050068.2013.874237

Steiner-Khamsi, G. and Waldow, F. (Ed). (2012) World Yearbook of Education 2012: Policy Borrowing and Lending in Education. London and New York: Routledge.

Unterhalter, E. (2009) Social Justice, Development Theory and the Question of Education In Cowen, Kazamias and Unterhalter (Eds) Internaional Handbook of Comparative Education Part Two, Springer, pp. 781-802.

Urry, J. and Larsen, J. (2011) The Tourist Gaze 3.0, London: Sage.

Viner, J. (1937) Studies in the Theory of International Trade, New York: Harper and Brothers Publishers.

Yu, Chung-Chi (2005) Between Homeworld and Alienworld: Waldenfels on Interculturality In Philosophy, Culture and Traditions, Vol. 3, pp. 25-38.

Waldenfels, B. (2007) The Question of the Other, New York: SUNY.

Waterkamp, D. (1997) Robert Ulich: Ideal Universalism: A German Emigrant's Contribution to Education Studies in the USA, Dresdner Universitätsverl. \& Universitätsbuchhandlung.

Wimmer, A. and Glick Schiller, N. (2002) Methodological nationalism and beyond: nation-state building, migration and the social sciences In Global Networks Vol. 2, No. 4, pp. 301-334. 